\title{
Role of Agriculture in ensuring Food Security
}

\author{
Malati Kaini \\ Ph.D. Scholar \\ Central Department of Rural Development \\ Tribhuvan University \\ Kathmandu, Nepal \\ Email: malatikaini@gmail.com \\ NEPAL
}

\section{ABSTRACT}

The 2007-2008 food crises and the renewed surge in food prices in 2010-2011 have exposed deep structural problems in the global food system and the need to increase food production. The World Food Summit of 1996 defined food security as existing "when all people at all times have access to sufficient, safe, nutritious food to maintain a healthy and active life". Despite Nepal has no worse food and nutrition security situation among SAARC countries, there are some districts where food is always in shortage. The explicit constitutional recognition of the right to food and other related provisions in articles 36 and 42 of the new constitution will be instrumental for implementing food security programs in the country. Food security for poor people is based on sustainable food production. Many proven technologies and improved practices have the promise to boost agricultural production and ensure food security in developing countries like Nepal. Food and Nutrition security program (FANUSEP) is one of the flagship programs of Agriculture Development Strategy 2015-2035 (ADS), which is in the first phase of its implementation. It aims at improving the food and nutrition security of the most disadvantaged groups of the population.

\section{Keywords: Food security, nutrition, agriculture, access to food, food availability, health}

\section{Introduction}

\subsection{Concept and definition}

The concepts that presently lie at the basis of "food security" and "nutrition security" were established in the early 1940s, during the Second World War, under the background of the severe hunger that affected numerous European populations. With the emergence of the world oil crisis and the food crisis in the period 1972-1974, the public interest in global and domestic food security grew very fast. These days, many developing countries like Nepal are implementing food and nutrition programs. With an ever-increasing population, it is essential that everyone has access to the food and drink they need to survive. Food security is important because everybody has to eat. So food is considered as a basic human right by the United Nations Universal Declaration of Human Rights. Article 25 of it includes the "right to a standard of living adequate for the health and well-being of himself and of his family, including food, clothing, housing, and medical care ..."

The World Food Summit of 1996 defined food security as existing "when all people at all times have access to sufficient, safe, nutritious food to maintain a healthy and active life". Food access refers to the affordability and allocation of food, as well as the preferences of individuals and households. Commonly, the concept of food security is defined as including both physical and economic access to food that meets people's dietary needs as well as their food preferences. Household food security exists when all members, at all times, have access to enough food for an active, healthy life.

\subsection{Food security situation in Nepal}

Despite Nepal has no worse food and nutrition security situation among SAARC countries, there are some districts where food is always in shortage. However, Nepal Demographic and Health Survey (NDHS), 2016 has shown that the national household food security is only $48.2 \%$ whereas in rural areas the percentage is only about $38.8 \%$. The severely food insecure households are about $10 \%$. Geographically, the mountain region is suffering more from food insecurity where the percentage of food secure households is $38.4 \%$ compared to terai where the statistics are about $51 \%$. The severely food insecure households in the mountain region are about $13.8 \%$ compared to $9.2 \%$ of 
the Terai region. State-wise the Karnali Province has the lowest level of food security (food-secure households are only $22.5 \%$ ) and the severely food-insecure households are about 17.5\% (NDHS, 2016). Out of 16 high hill districts such as Taplegunj, Sankhuwasabha, Solukhumbu, Dolkha, Sindhupalchowk, Rasuwa, Manang, Mustang, Dolpa, Mugu, Humla, Jumla, Kalikot, Bajura, Bajhang, and Darchula; 12 districts, except Sankhuwasabha, Solukhumbu, Dolkha, Sindhupalchowk have food deficit situation. Nation wise Nepal is in a food surplus situation in most of the years. The problem is in distribution.

\subsection{Constitutional provision}

In the context of Nepal, right relating to food is one of the fundamental rights provisioned in our constitution. The explicit constitutional recognition of the right to food and other related provisions in articles 36 and 42 of the new constitution is very relevant and timely. It will be instrumental in the implementation of food security programs. The National Human Rights Commission, members of the Constitution Assembly, Nepal Bar Association, farmers groups, and human rights activists were very active for their collective advocacy in favor of the constitutional status for the human right to adequate food. FAO Nepal supported the Government of Nepal to promote, protect and monitor human rights in policy formulation, program planning and legislation drafting on food security and right to food in Nepal.

\subsection{Major policy, plan, strategy and program}

Major policy, plan, strategy and program related to food and nutrition security are listed below:

- Agriculture Development Strategy (ADS), 2015-2035;

- Agro-biodiversity Policy, 2007; • Dairy Development Policy, 2007; • Trade Policy, 2009; National Agricultural Policy, 2004;

- Multi-sectoral Nutrition Plan (MSNP) I \& II;

- National Seed Policy, 2000;

- Agri-business Promotion Policy, 2006;

- NeKSAP: Nepal Food Security Monitoring System (NeKSAP); and

- Agriculture and Food Security Project (AFSP) 2013-2018.

Some of them are directly related to food and nutrition security and some are indirectly related. The purpose of agricultural policy should be to develop appropriate and sustainable guidelines for promotion of efficient agricultural practices that guarantee food security, generate employment for citizens, provide raw materials for all agricultural industries, and also to acquire foreign currency. Agriculture can work with other sectors of the economy to achieve faster development, poverty reduction and food security.

\section{Objective}

The main objective of this study is to identify the roles of agriculture to ensure food security sustainably in the country.

\section{Methodology}

Methodologies adopted to prepare this paper were: a) review of relevant documents; and b) consultation with the experts.

\section{Multidimensional aspects of food security}

There are multidimensional aspects of food security and they take into consideration four characteristics both in quantitative and qualitative terms:

I. Food availability-availability of foodstuffs in sufficient amount and adequate quality, supplied from the domestic production or from import (food aid included).

II. Access to food-everybody has access (rights) to adequate resources to get adequate and nourishing food; from economic perspective, accessibility means the possibility of individuals and households to procure food either from their own production or by buying it, without sacrificing other basic needs; physical accessibility means access to food for all persons, for physically vulnerable persons included, such as children, sick people, disabled people or elderly people. 
III. Availability and access stability-the access to food should not be endangered by the emergence of sudden shocks (for instance an economic crisis or adverse weather conditions) or cyclical events (e.g. seasonal food insecurity).

$\boldsymbol{I V}$. Health-the foodstuffs should meet the nutritional requirements, taking into consideration the age, living conditions, health, work, gender, etc.; at the same time, food must be produced under safety conditions for people and free from noxious substances such as pollutants from industrial and agricultural processes, including residues of pesticides, hormones, and veterinary drugs.

\section{Challenges}

Many challenging issues are having significant yet uncertain impacts on food security. Some of the challenges areas listed below:

-Low production and productivity

- Fragmented land and scattered production

- Subsistence farming with traditional practices

-population pressure

- Low in climate resilience, climatic shocks, and events

- Low percentage of irrigated land

-High costs of production and soaring food prices

-Transportation and distribution problem

-Inadequate food buffer stock

-Inadequate access to food diversity

Food insecurity remains a serious challenge for Nepal. Agricultural growth provides the principle pathway to tackle this problem. For agriculture to make this contribution, land, and labor productivity have to grow to start with. Adaptation strategies and policy responses to global change, including options for handling water allocation, land use patterns, food trade, post-harvest food processing, and food prices and safety are urgently needed. Public investment has to lead programs in irrigation and infrastructure, technology generation, prevention of animal and crop diseases and pests and natural resource conservation. It is equally important to take steps to improve access to nutrition and safe food for vulnerable communities.

\section{Agriculture and food security}

Food security is most often associated with food self-sufficiency and with the need to produce more food. For the low-income economies, in which a high percentage of the population lives in the rural area and their incomes depend on agriculture, food production growth could be an important element in food security increase, from the perspective of increased incomes for the small farmers. However, food security has much closer links with poverty problems, labor employment, and income generation. In the developed countries, the focus lies on food quality and safety and on the social protection of different categories of persons.

The food security for poor people is based on sustainable food production, and in this context, the rational use of resources has an essential role in achieving self-sufficiency in food production. Sustainable agriculture has as main objectives the optimization of soil productivity and at the same time the conservation of basic natural resources. This means that in the agricultural production systems equilibrium will be maintained between inputs and outputs, between investments and benefits, in the conditions of ensuring an adequate environment quality and promoting an overall sustainable economy. As the rational use of natural resources plays an essential role in agricultural production, one of the most important challenges in reaching food security consists of the increase in food production under the background of soil degradation. While the expansion of food production is vital for achieving food security and reducing poverty, it is also associated with negative environmental consequences. Agricultural activities that underpin food production have been recognized as a major contributor to greenhouse gas emissions, water scarcity and pollution, land degradation, and biodiversity loss. Unsustainable natural resource management also has adverse socio-economic impacts.

Increasing food production along with maintaining natural resources is not an easy task. The growth rate of major cereal yields (wheat, rice, and corn) is declining. Increasing food production requires resource-friendly 
methods, and this will require the development of new mechanization technology. While one of the major constraints on developing and modernizing production in developing countries is the low level of engineering technology in agriculture. Despite its many values and undeniable benefits, which are briefly mentioned above, mechanization is still considered as an input, such as other inputs, like fertilizers, seeds, and chemical protection products and in the most optimistic way, it is one of the combined management tools aimed at maximizing farmers' productivity and profits. Studies show that crop production is more beneficial in areas where agricultural mechanization is provided. According to the research conducted in mechanized agricultural areas, yields were significantly higher than in nonmechanized areas. The use of pesticides was also more effective, and the land and fertilizers were used optimally. This is the need of the world today, achieving food security by preserving natural resources for future generations. Many proven technologies and improved practices have the promise to boost agricultural production and ensure food security in developing countries. Here is where agricultural mechanization plays its role, and therefore developing countries need to design a new strategy based on mechanization.

The 2007-2008 food crises and the renewed surge in food prices in 2010-2011 have exposed deep structural problems in the global food system and the need to increase resources and foster innovation in agriculture to accelerate food production. The development of new technology and management systems in agriculture does not occur overnight, it requires long term support for R\&D and an environment of cooperation, experimentation and learning with efficient and free flow of information and a shared research agenda. Adequate and long term financial support from national and international public sources is most important. The adoption of new technology and innovative practices in production requires an enabling policy framework and adequate investment in infrastructure, capacity development among farmers, as well as access to inputs, credit, and markets in a process where governments play a key role in directing resources and creating incentives to ensure these conditions. The radical transformation of agriculture for food security is possible when there is political will and long term commitment from national and international stakeholders. The challenge of increasing agricultural production for food security nowadays is far more complex than in the past and will require strengthened systems of innovation with the flexibility to respond to the specific needs of farmers in a variety of ecological and socio-economic contexts (Lipton, 2010), without expanding the agricultural frontier and with sustainable use of natural resources.

Agriculture and food security are characterized by gendered dimensions in that women play a key role in agricultural production, food processing, and marketing. They play a decisive role in dietary diversity and are responsible for nutrition in the home. In addition, women are involved in the production and domestication of plants and animals; they are knowledgeable in seed selection and vegetative propagation; they understand how plants and animals grow and reproduce, and they plant trees. While the roles of women in agriculture vary widely by region, age, ethnicity and social station, their participation rates in the agricultural labor force in NEPAL are probably the highest in the SAARC countries.

\section{Current food security programs}

Food and Nutrition security program (FANUSEP) is one of the flagship programs of Agriculture Development Strategy 2015-2035 (ADS). It aims at improving the food and nutrition security of the most disadvantaged groups of the population. It consists of three subprograms: the Nepal Food Security Project (NAFSP), the Food and Nutrition Security Action Plan (FNSP) and Food and Nutrition Security Enhancement Project (FANSEP) implemented to complement NAFSP and FNSP. The commonality of the subprograms of FANUSEP is to target the poor, the disadvantaged groups and the geographically disadvantaged areas. The program is promoting interventions that improve productivity, livelihood, and nutritional practices of targeted beneficiaries including pregnant and lactating women farmers. Nepal's multi-sectoral Nutrition Plan (MSNP 2013-2017) has also identified food and nutrition security as a key issue and the project was able to contribute to the achievements of MSNP to some extent.

The Government of Nepal (GoN) designed Agriculture and Food Security Project (AFSP) to enhance food and nutrition security of the residents of selected location of 19 project districts in mid and far western regions of Nepal with the competitive grant support of US \$ 46.5 million from GAFSP and US\$11.5 million GoN. The project was for 5 years period starting from 1st April 2013 to 31st March 2018. It was envisaged that food security would be realized through increased food availability, made possible by increased productivity of both crop and livestock 
whereas nutrition security would be realized through improved dietary intake, promotion of diversified diets, and improved feeding and caring practices for pregnant and nursing women and children below 2 years of age.

Although various collaborative efforts have been made to promote nutrition-sensitive agriculture in Nepal; as it is a multi-dimensional and multi-functional nature, need more attention for collaborative efforts on planning, implementation, monitoring/feedback and sharing results and lessons learned.

\section{Conclusion}

Food security in Nepal is associated with food self-sufficiency and food self-sufficiency can be achieved through the implementation of production-oriented programs. The present-day agriculture of Nepal has been feminized due to outmigration of youths. Women are playing a key role in agricultural production, food processing, and marketing. Hence, their role in food security is vital. Studies show that agriculture production is more beneficial in areas where agricultural mechanization is provided. Research should be focused on developing women-friendly farming machines.

\section{References}

Arend, E. (2011). “Gender, IFIs and Food Insecurity Case Study: Ethiopia," Gender Action, Washington DC.

Bingxin Y., \& Lingzhi, Y. (2013). A typology of food security in developing countries. China Agricultural Economic Review, 5 (1): 36 Emerald Publishing.

FAO (Food and Agriculture Organization). (2011). The State of Food and Agriculture 2010/2011: Women in Agriculture - Closing the Gender Gap for Development. Rome: Food and Agriculture Organization of the United Nations.

FAO (Food and Agriculture Organization)., IFAD (International Fund for Agricultural Development)., UNICEF (United Nations International Children's Emergency Fund)., WFP (World Food Programme)., \& WHO (World Health Organization). (2017). The State of Food Security and Nutrition in the World. Building resilience for peace and food security. Rome: Food and Agriculture Organization.

ICIMOD (International Centre for Integrated Mountain Development). (2016). Food Security Information System for Nepal, retrieved from http://geoapps.icimod.org/npfoodsecurity/.

Kruzslicika, M. (2014). Food security through sustainable agriculture. Agricultural Economics and Rural Development, New Series, Year XI, 2, 195-202.

Lipton, M. (2010). From policy aims and small-farm characteristics to farm science needs. World Development, 38 (10), 1399-1412.

MoAD (Ministry of Agricultural Development). (2016). Agriculture Development Strategy (ADS) 2015 to 2035, Government of Nepal. Singhdurbar, Kathmandu, Nepal: Ministry of Agricultural Development.

MoAD (Ministry of Agriculture Development). (2016). Food and Nutrition Security Plan of Action of Nepal. Singhdurbar, Kathmandu, Nepal: Ministry of Agricultural Development.

MoALMC (Ministry of Agriculture, Land Management and Cooperatives). (2018). Status Report on Food and Nutrition Security in Nepal. Singhdurbar, Kathmandu, Nepal: Ministry of Agriculture, Land Management and Cooperatives.

NeKSAP (Nepal Food Security Monitoring System). (2018). Brief on Food security situation in Nepal. Retrieved from http://www.neksap.org.np/ 